\title{
Natural Infection of Sorghum by Foxtail Mosaic Virus in Kansas
}

Dallas L. Seifers, Associate Professor, Kansas State University, Agricultural Research Center-Hays 67601-9228; Tom L. Harvey, Professor, Department of Entomology, Kansas State University, Manhattan 66506; Steve Haber, Research Scientist, Cereal Research Center, Agriculture \& Agri-Food Canada, 195 Dafoe Road, Winnipeg, Manitoba, Canada; Y. M. She and Igor Chernushevich, Postdoctoral Fellows, and Werner Ens and Kenneth G. Standing, Professors, Department of Physics, University of Manitoba, Winnipeg, Manitoba, Canada

\section{ABSTRACT}

Seifers, D. L., Harvey, T. L., Haber, S., She, Y. M., Chernushevich, I., Ens, W., and Standing, K. G. 1999. Natural infection of sorghum by foxtail mosaic virus in Kansas. Plant Dis. 83:905-912.

Sorghum (Sorghum bicolor) was infected by a mechanically transmissible, flexuous, rod-shaped virus. Antiserum made against the purified virus reacted specifically in enzyme-linked immunosorbent assay to the virus and to the potexvirus foxtail mosaic virus (FoMV), indicating that the sorghum virus was an isolate of FoMV. Comparison of the sorghum isolate (H93) to FoMV PV 139 showed that $\mathrm{H} 93$ differed biologically by causing severe symptoms in sorghum, not readily infecting certain barley lines, and causing only faint symptoms in barley. At the molecular level, the capsid of $\mathrm{H} 93 \mathrm{had}$ a mass of $23.9 \mathrm{kDa}$ and 217 amino acid residues compared with $23.7 \mathrm{kDa}$ and 215 residues previously reported for the nucleic acid sequence of FoMV. The amino acid sequences of the two viruses were greater than $96 \%$ identical. They varied by having four substitutions, one deletion, and three insertions between residues 66 and 67 . This is the first report of natural infection of sorghum by FoMV, thus extending its host range among cereal crops.

Additional keywords: host symptoms

Sorghum (Sorghum bicolor) is an important and widely grown crop in the Great Plains region of the United States. In Kansas, it can be infected naturally by maize dwarf mosaic virus (MDMV) (15), sugarcane mosaic virus strain MDMV-B (SCMV-MDMV-B) (15), Johnson grass mosaic virus (JGMV) (D. L. Seifers, unpublished), and wheat streak mosaic virus (19). In 1993, sorghum was observed with mosaic symptoms, necrotic streaking, and whole leaf necrosis at Hays, Kansas. Some of the plants were infected with MDMV, SCMV-MDMV-B, and JGMV, but some were infected by an unidentified, mechanically transmissible virus.

We present evidence that the unidentified virus is an isolate of foxtail mosaic potexvirus (FoMV), previously reported only from green foxtail (14), and that this sorghum isolate of FoMV differs from the green foxtail isolate at the biological and molecular levels.

Corresponding author: D. L. Seifers E-mail: dseifers@oz.oznet.ksu.edu

Contribution 99-348-J from the Kansas Agricultural Experiment Station, Manhattan 66506. Research was supported in part by a grant from the Kansas Sorghum Commission.

Accepted for publication 10 June 1999.

Publication no. D-1999-0706-02R

(C) 1999 The American Phytopathological Society

\section{MATERIALS AND METHODS}

Virus source and maintenance. The FoMV PV 139 isolate was obtained from the American Type Culture Collection (1) and was maintained in barley (Hordeum vulgare) cv. Westford and occasionally in sorghum cv. GATE 76, and the sorghum isolate (H93) from Kansas was maintained in GATE 76 sorghum. Plants were inoculated manually with 1:10 (wt/vol) extracts from source plants as described previously (19). Inoculated plants (PV 139 or H93) were held in separate growth chambers at $20^{\circ} \mathrm{C}$ with $12 \mathrm{~h}$ of illumination (500 $\mu \mathrm{E} \cdot \mathrm{s}^{-1} \cdot \mathrm{m}^{-2}$ ) per day. At 14 days postinoculation, infected tissue was harvested and frozen at $-80^{\circ} \mathrm{C}$ for later use.

Indirect enzyme-linked immunosorbent assay (ELISA). The procedure used was as previously described (19). Leaf tissue was ground at a 1:30 (wt/vol) dilution in coating buffer (6), and antiserum made against $\mathrm{H} 93$ was used at a 1:1,600 dilution $(0.625 \mathrm{mg} / \mathrm{ml})$ made from a 1 $\mathrm{mg} / \mathrm{ml}\left(A_{280 \mathrm{~nm}} 1.4\right)$ stock. The goat antirabbit antibody:alkaline phosphatase conjugate $(1: 3,000$, vol/vol; Fisher ScientificCat. No. 4050-04) was diluted using ELISA blocking buffer. All samples, antibody solutions, and substrate solutions were used at a $0.200-\mathrm{ml}$ volume. Substrate ( $p$-nitrophenyl phosphate, $0.714 \mathrm{mg} / \mathrm{ml}$ ) in substrate buffer (6) was added, the plates were incubated at room temperature, and the absorbance (405 nm) was measured after 30 min (Titer Multiskan microelisa plate reader, Flow Laboratories, Inc.,
Huntsville, AL). The minimum positive threshold for FoMV-H93 antiserum was set at 0.060 for barley, sorghum, and wheat, because plants of these species having values as low as 0.054 and 0.059 were infective to GATE 76 sorghum.

Minipurification, sodium dodecyl sulfate-polyacrylamide gel electrophoresis (SDS-PAGE), estimation of relative molecular masses, and Western blotting of proteins. The FoMV proteins were extracted and minipurified following the procedure of Lane $(11,12)$. Relative molecular masses were calculated using a densitometer to determine electrophoretic mobility compared with protein standards (18). The method of Laemmli (10) was used for SDS-PAGE. Electrophoresis was in a $10 \%$ gel, $0.75 \mathrm{~mm}$ thick, using a Hoefer SE 600 apparatus (Amersham Pharmacia Biotech, Inc., Piscataway, NJ) for $2.5 \mathrm{~h}$ (volts and $\mathrm{mA}$ set at 400 and 60, respectively). Proteins were stained with Coomassie blue $(0.125 \%$ Coomassie blue R-250, 30\% methanol, and 10\% acetic acid). Mass standards were: myosin, rabbit muscle (205 kDa); $\beta$-galactosidase (116 $\mathrm{kDa}$ ); phosphorylase $\mathrm{b}$, rabbit muscle ( 97.5 $\mathrm{kDa})$; albumin bovine (66 kDa); albumin, egg (45 kDa); and carbonic anhydrase, bovine erythrocyte $(29 \mathrm{kDa})$. Electrophoresis was done in a Hoefer SE 600 apparatus for $2.5 \mathrm{~h}$ (volts and $\mathrm{mA}$ set at 400 and 60, respectively).

Electrophoretic analyses were conducted a minimum of two times using extracts from different symptomatic plants. Healthy plant tissue samples were treated and tested identically.

For Western blotting, plant extractions and separations by SDS-PAGE and transfer of proteins onto nitrocellulose membranes were done as described (18). Alkaline phosphatase antirabbit goat antibody conjugate (1:3,000 dilution, Fisher Scientific 4050-04) was used for immunoblotting as described by Bollig and Edelstein (4). Kaleidoscope markers (161-0324; Bio-Rad Laboratories, Hercules, CA) were used in Western blots as molecular mass standards. Western blotting was done in a TE 50 Transphor unit (Hoefer) at $100 \mathrm{~V}$ for $1 \mathrm{~h}$.

Infectivity assays. Plants (two-leaf stage) were inoculated manually with 1:10 (wt/vol) extracts as described previously (15). Inoculated plants were grown in a greenhouse for 2 weeks under natural light 
at 18 to $30^{\circ} \mathrm{C}$. Data were subjected to ANOVA.

Electron microscopy procedures. Symptomatic GATE 76 sorghum leaf tissue was cut with a new razor blade, and the cut edge of the leaf was dipped into a drop of $1 \%$ aqueous ammonium molybdate $(\mathrm{pH}$ $6.0)$ or $1 \%$ sodium phosphotungstate $(\mathrm{pH}$ 7.0). Separate drops of this solution were placed on carbon-stabilized, Formvarcoated grids and viewed in a Phillips 201 electron microscope at 60 or $80 \mathrm{kV}$. A minimum of four grids was viewed for each virus preparation.

Virus purification. The sorghum isolate of FoMV was purified as previously described for Agropyron mosaic virus (16) and wheat streak mosaic virus (19).

Antiserum. Antiserum was prepared as previously described except that TiterMax (Vaxcel, Inc., Norcross, GA) was substituted for Freund's incomplete adjuvant (17). Virus was mixed (1:1 vol/vol) with adjuvant and was injected twice, with the second occurring 2 weeks after the first injection. Approximately $0.300 \mathrm{~g}$ of purified virus was injected on each occasion. The rabbit was bled 2 weeks prior to the first immunization to obtain a normal serum control and then on a weekly basis for 5 weeks. Antiserum from the fourth sample was used for research. The IgG fraction was obtained by ammonium sulfate pre- cipitation as previously described (17). A $1: 12,800$ dilution ( $\mathrm{vol} / \mathrm{vol}$ ) of the $\mathrm{IgG}$ against a 1:3,125 dilution of the purified sorghum-infecting isolate of FoMV had a reading of 0.110 by indirect ELISA, with healthy sorghum having a value of 0.001 . The antiserum was used routinely at a $1: 1,600$ dilution ( $\mathrm{vol} / \mathrm{vol})(0.625 \mu \mathrm{g} / \mathrm{ml})$, which had readings in indirect ELISA of 0.548 and 0.020 for symptomatic, FMVH93-infected (14 days postinoculation), and healthy sorghum (1:5, wt/vol dilution), respectively.

Antisera to FoMV-PV 139 and Panicum mosaic virus were provided by R. L. Bowden (Kansas State University, Manhattan). Antisera to Agropyron mosaic virus and wheat streak mosaic virus (16), and maize dwarf mosaic virus, sugarcane mosaic virus strain MDMV-B, and JGMV (17) were prepared as described previously. Brome mosaic virus antiserum (PVAS 178) and sorghum mosaic virus (PVAS 323) antiserum were obtained from the American Type Culture collection (Rockville, MD).

Host range. Grasses and sources of seed used in host range studies are listed in Table 1. Seeds were planted into soil-filled "plant cells" (Stuewe \& Sons, Corvallis, OR) in a greenhouse, and seedlings were inoculated mechanically at the two- to three-leaf stage with extracts prepared

Table 1. Names and seed sources of species used in host range experiments for foxtail mosaic virus isolates PV139 and H93

\begin{tabular}{|c|c|c|}
\hline Plants & Common name or variety & Seed source ${ }^{z}$ \\
\hline Aegilops cylindrica & Jointed goat grass & 5 \\
\hline Aegilops juvenalis & Goat grass & 5 \\
\hline Aegilops triuncialis & Goat grass & 5 \\
\hline Agropyron elongatum & Tall wheat grass & 3 \\
\hline Alopecurus pratensis & Meadow foxtail & 9 \\
\hline Andropogon hallii & Sand garden Blue stem & 8 \\
\hline Briza maxima & & 9 \\
\hline Bromus inermis & Smooth brome & 3 \\
\hline Buchloe dactyloides & Buffalo grass & 9 \\
\hline Coix lacryma-jobi & & 6 \\
\hline Hordeum vulgare & & 4 \\
\hline Lagurus ovatus & & 7 \\
\hline Lolium perenne & Perennial rye grass & 2 \\
\hline Oryza sativa & Rice & 5 \\
\hline Panicum antidotale & & 7 \\
\hline Panicum capillare & Witch grass & 7 \\
\hline Panicum miliaceum & Proso millet & 1 \\
\hline Panicum virgatum & Switch grass cv. Blackwell & 8 \\
\hline Paspalum notatum & & 2 \\
\hline Pennisetum glaucum & Pearl millet cv. C-130 & 1 \\
\hline Phalaris arundinacea & Reed canary grass cv. NCR 1 & 9 \\
\hline Secale cereale & var. Mayton & 1 \\
\hline Setaria faberi & Giant foxtail & 2 \\
\hline Setaria italica & Foxtail millet cv. White Wonder & 10 \\
\hline Setaria viridis & Green foxtail & 2 \\
\hline Sorghum bicolor & cv. GATE 76 & 1 \\
\hline Sorghum halepense & Johnson grass & 2 \\
\hline Tripsacum dactyloides & Eastern gama grass & 3 \\
\hline Zea luxurians & & 6 \\
\hline
\end{tabular}

z 1 = Kansas State University Agricultural Experiment Station-Hays; 2 = Valley Seed Service, Fresno, CA; 3 = Sharp Bros. Seeds, Healy, KS; 4 = Townsend Seed Inc., Townsend, MT; 5 = National Small Grains Collection, USDA-ARS, Aberdeen, ID; $6=$ North Central Regional Plant Introduction Station, Pullman, WA; 7 = Northrup King Co., Minneapolis, MN; 8 = USDA-SCS, Manhattan, KS; 9 = Western Regional Plant Introduction Station, Pullman, WA; $10=$ David Baltensperger University of Nebraska, Scottsbluff. from sorghum systemically infected with FMV-H93 as described above. Following inoculation, the plants were held in the greenhouse under natural lighting at 16 to $29^{\circ} \mathrm{C}$, rated for symptoms 28 days later, and tested by back-inoculation (using youngest leaf from test plant) to GATE 76 sorghum. Following preparation of antiserum against FoMV-H93, plants were tested for infection by ELISA as described above. Symptomatic plants were tested individually, and nonsymptomatic plants were bulked. Controls consisted of mock-inoculated GATE 76 sorghum infected with H93. Identity of plants tested from field locations was established using the Flora of the Great Plains as a guide (7).

Time of flight mass spectroscopy (TOFMS) mass determinations and amino acid sequencing. Purified capsid proteins of FoMV-H93 (purified as described above) were lyophilized and sent to the University of Manitoba, where the masses and amino acid sequences of the capsid proteins were determined by TOFMS as described previously (21).

Virus transmission. Biotype I greenbug (Schizaphis graminum), corn leaf aphid (Rhopalosiphum maidis), and oat bird cherry aphid (Rhopalosiphum padi) were used to determine vector relations. Adult aphids of each species were maintained on healthy GATE 76 sorghum. Sorghum from which aphids were acquired was verified virus free by ELISA (as described above) prior to use of aphids in experiments. Ten aphids were transferred manually (using a $10 / 0$ artist's brush) to separate symptomatic GATE 76 sorghum plants (testing positive in ELISA for FoMV) and given a 24-h acquisition access time. Aphids were then removed, and 10 aphids of each species were transferred with the brush to each of 10 GATE 76 plants and 5 barley plants (two-leaf stage). Following infestation, each plant was covered with a vented plastic cage (designed to prevent contamination by wheat curl mites) as previously described (20) to prevent contamination of the plants by other aphid species. Aphids were allowed a 24-h feeding period and then removed by fumigation (3-h exposure in a sealed box containing a Vapona strip; active ingredient 2,2-dichlorovinyl dimethyl phosphate). Assay plants were held in the greenhouse $\left(18\right.$ to $\left.33^{\circ} \mathrm{C}\right)$ and assayed 3 weeks later by ELISA (newest leaf) against antiserum prepared to H93. Healthy controls consisted of sorghum plants infested separately as described above, but by aphids that had previously fed on healthy sorghum only. Each aphid species was collected at the Kansas State UniversityAgricultural Research Center-Hays and identified by T. L. Harvey. Voucher specimens were deposited in the Research Collection of Insects, Department of Entomology, Kansas State University. Vector experiments were performed three times for each aphid species. 


\section{RESULTS AND DISCUSSION}

On 7 September 1993, 17 plants displaying different symptoms were sampled from naturally infected, field-grown sorghum (cv. Canex, Sharp Bros. Seeds, Healy, KS). Symptoms ranged from fine dots coalescing to form mosaic areas to necrotic spots and streaks, in addition to mosaic areas. Three smooth brome (Bromus inermis) plants that had faint mosaic symptoms and were growing adjacent to the sorghum also were sampled. These sorghum and smooth brome plants were tested by ELISA with antisera made against MDMV, SCMV-MDMV-B, and JGMV. Ten sorghum samples, (1, 3, 4, 6, 8, $10,12,13,15$, and 16) tested positive for JGMV, and one each tested positive for MDMV (sample 17) and SCMV-MDMV-B (sample 2). Five sorghum $(5,7,9,11$, and 14) and the three smooth brome samples $(18,19$, and 20) were negative against all antisera. No necrotic symptoms were observed in any sample testing negative in ELISA. However, tissue extracts from samples 5, 7, 9, 11, 14, 18, 19, and 20 were infective to GATE 76 sorghum, as was sample 8 (testing positive in ELISA for JGMV). When samples of the symptomatic GATE 76 sorghum were tested by ELISA (1:30 wt/vol dilution) against the above antisera, only samples 8 and 20 tested positive for JGMV. The positive reaction for JGMV from sorghum plants inoculated with extracts from sample 20 probably resulted from very low virus titers in smooth brome that were missed in the ELISA, since brome is not listed as a systemic host for JGMV (13).

Minipurification and SDS-PAGE (Fig. 1) of extracts from the GATE 76 sorghum assay plants showed a single unique band (flanked by solid black arrows) present only in extracts from symptomatic plants (negative in ELISA) but not present in healthy controls in lane 14. Lanes 8 and 9 were loaded with extracts from samples testing positive in ELISA for JGMV. These lanes also displayed a band (horizontal, solid black arrow) at the same position as the samples negative in ELISA (lanes 1 to 7). The upper band in lanes 8 and 9 corresponds to that of pure isolates of JGMV in lanes 10 and 11. Lanes 12 and 13 contain extracts from sorghum infected with MDMV-infected (solid white arrow) and SCMV-MDMV-B-infected (dashed white arrow) sorghum, respectively. The bands at the same position as those from sorghum infected by the control JGMV in samples 8 (lane 9) and 20 (lane 8) confirm the ELISA results of infection by JGMV. Infection by $\mathrm{H} 93$ is indicated by the unique protein (solid arrow) associated with symptomatic sorghum negative in ELISA. The relative molecular masses of the bands (flanked by horizontal black arrows) present in the tissue negative in ELISA were estimated by electrophoretic mobility and ranged from $23.6 \mathrm{kDa}$ to $24.6 \mathrm{kDa}$.

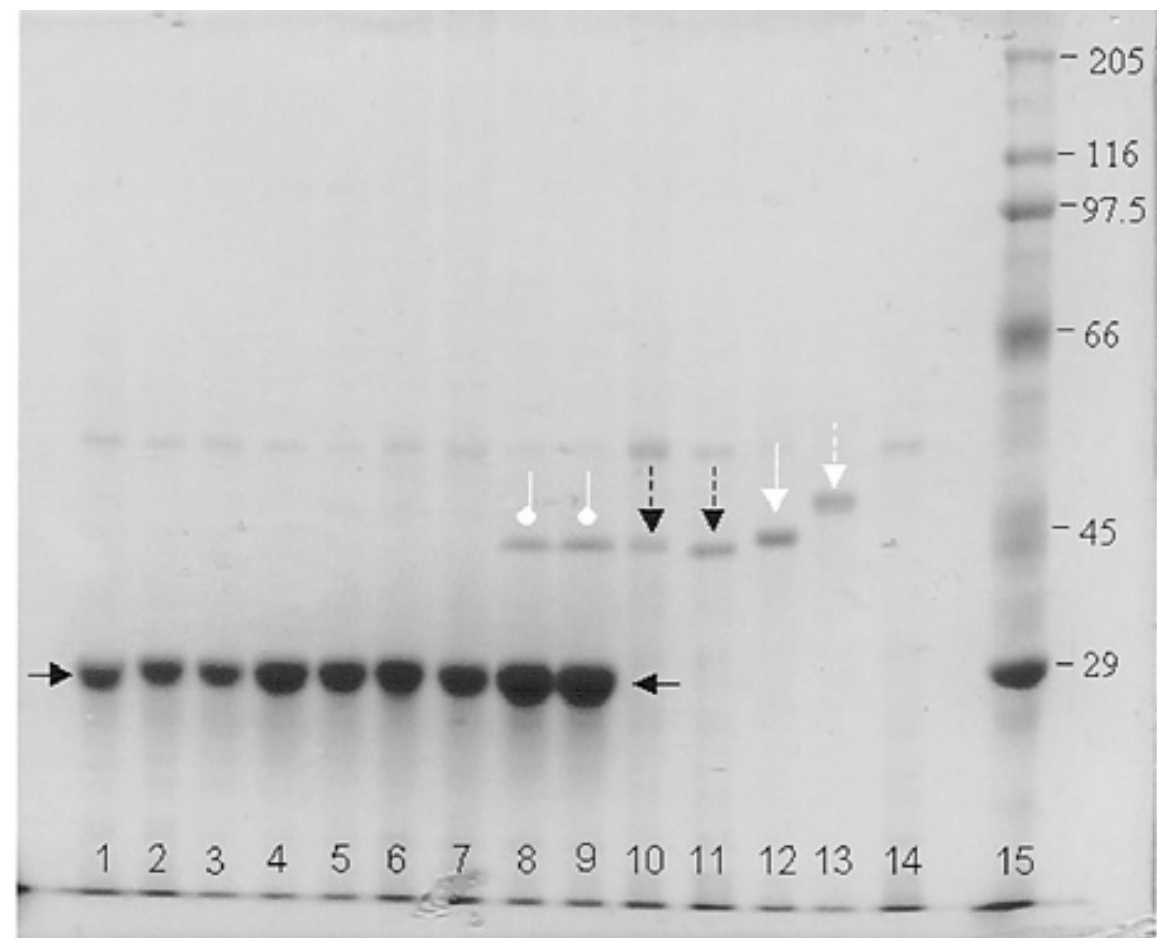

Fig. 1. Proteins from symptomatic and healthy sorghum plants concentrated by minipurification and separated by sodium dodecyl sulfate-polyacrylamide gel electrophoresis. Lanes (1 to 9) isolates $5,7,9,11,14,18,19,20$, and 8 of foxtail mosaic virus, (10) Johnson grass mosaic virus (JGMV) (D. T. Gordon isolate), (11) Kansas isolate of JGMV, (12) maize dwarf mosaic virus (Kansas isolate), (13) sugarcane mosaic virus strain MDMV-B (Kansas isolate), (14) healthy sorghum, and (15) molecular mass standards. Numbers to right of standards are in $\mathrm{kDa}$. Black arrows mark the band unique to symptomatic sorghum testing negative in enzyme-linked immunosorbent assay. Dashed black arrows, solid white arrow, and dashed white arrow mark the location of capsid proteins of JGMV, MDMV, and SCMV-MDMV-B, respectively. Round white arrows mark bands equivalent to the JGMV bands (black dashed arrows in lanes 10 and 11) in tissue testing positive against JGMV antiserum.

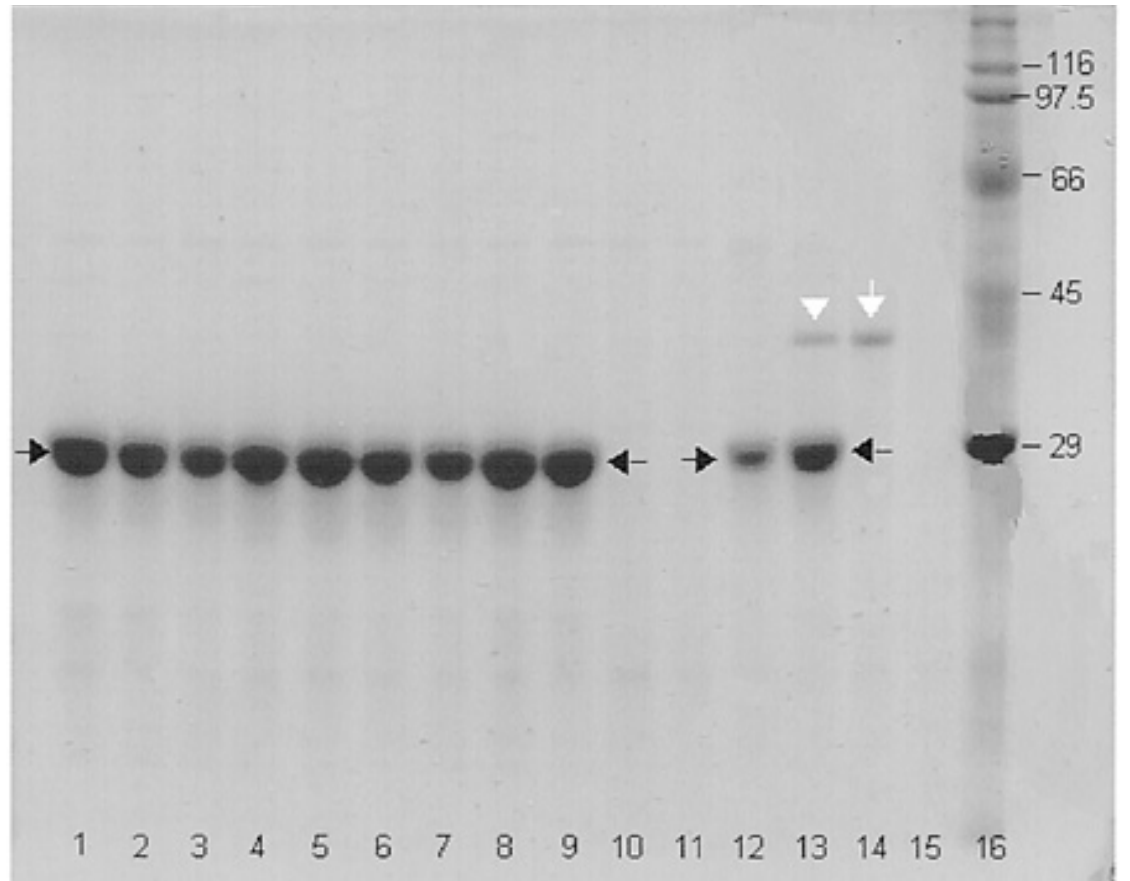

Fig. 2. Protein concentrated from the second leaf of Westford barley or GATE 76 sorghum (either healthy or infected) by minipurification and separated by sodium dodecyl sulfate-polyacrylamide gel electrophoresis. Lanes (1 to 9) isolates 5, 7, 9, 11, 14, 18, 19, 20, and 8 of foxtail mosaic virus (FoMV) in barley, (10) barley inoculated with Johnson grass mosaic virus (JGMV) (D. T. Gordon isolate), (11) healthy barley, (12) isolate 5 of FoMV in GATE 76 sorghum, (13) isolate 20 of FoMV in GATE 76 sorghum, (14) JGMV (D. T. Gordon isolate) in GATE 76 sorghum, (15) healthy sorghum, and (16) molecular mass standards, respectively. Numbers to right of standards are in $\mathrm{kDa}$. Black arrows mark location of band unique to symptomatic sorghum testing negative in enzyme-linked immunosorbent assay. White arrow (lane 14) marks the location of JGMV capsid protein and black arrow head marks the equivalent band in the tissue testing positive for JGMV in enzyme-linked immunosorbent assay but also infected by isolate 20 of FoMV. 
Extracts from the sorghum plants represented in lanes 1 to 9 (Fig. 1) were used to inoculate the first leaf of Westford barley at 6 days following seeding. The second leaf of the barley plants had very faint symptoms, and all plants inoculated with each isolate tested negative in ELISA. When the remaining tissue of leaf 2 was bulked and analyzed by minipurification and SDS-PAGE, the unique band was again present (horizontal, solid black arrow) (Fig. 2). The JGMV capsid protein band present in sample 8 (lane 9) and sample 20 (lane 8) was absent as expected, because barley is not a systemic host for JGMV (13), thus confirming the negative reaction in ELISA against JGMV antiserum. Extracts from isolate 20 maintained in GATE 76 sorghum (lane 13) showed the JGMV capsid (white arrow head), which is at the same location as the control JGMV in lane 14 (solid white arrow). Lane 10 represents barley inoculated with the same JGMV isolate represented in lane 14, and lanes 11 and 15 were loaded with extracts from healthy barley and sorghum, respectively. The molecular masses of the bands flanked by horizontal white arrows in lanes 1 to 9 of Figure 2 ranged from 22.5 to 24.9 $\mathrm{kDa}$ (as estimated by electrophoretic mobility). When relative mass of isolate 5 was evaluated a third time by SDS-PAGE, a value of $23.7 \mathrm{kDa}$ was calculated; the resulting average of the three values was $24.3 \mathrm{kDa}$. The unknown virus thus could infect barley but cause only faint symptoms, could be freed of JGMV by passage through barley, and had a capsid protein with a mass of approximately $24 \mathrm{kDa}$ (average of three experiments using isolate $5)$. Based on these results, isolate 5 was considered as representative and used for all remaining experiments with the designation $\mathrm{H} 93$.

Inoculation of other plant species with H93 showed that it was infectious (determined by backassay to GATE 76 sorghum) to corn cv. OH 28 (Zea mays), smooth brome (Bromus inermis), Johnson grass (Sorghum halepense), oat cv. Larry (Avena sativa), rye cv. Mayton (Secale cereale), and wheat cv. Tomahawk. Only corn (faint mosaic), smooth brome (faint mosaic), and sorghum (severe mosaic) became symptomatic. The virus infecting the GATE 76 sorghum assay plants was minipurified, and the proteins were separated by SDS-PAGE. All symptomatic sorghum extracts had only the $24 \mathrm{kDa}$ band present in SDS-PAGE (data not shown).

When symptomatic leaves from GATE 76 sorghum infected by H93 were used for leaf dips, flexuous rod-shaped virions were observed (data not shown). The preparations contained particles of different lengths, the most common measuring 408 $\times 12 \mathrm{~nm}$. Four hundred virions gave the following length measurements: $403 \mathrm{~nm}$ (12\%), $404 \mathrm{~nm}(21 \%), 408 \mathrm{~nm}(22 \%), 414$ nm (31\%), 436 nm (14\%).

Particle morphology and length, although somewhat shorter, suggested that H93 might belong to the potex group of viruses (9). In 1967, the potexvirus FoMV was isolated from green foxtail (Setaria viridis) in Kansas (14). Therefore, we tested the FoMV-PV 139 isolate, H93, and other viruses against antiserum made to

Table 2. Reaction ${ }^{\mathrm{y}}$ in enzyme-linked immunosorbent assay (ELISA) of extracts (1:30, wt/vol) of GATE 76 sorghum infected with the type specimen (PV139) of foxtail mosaic virus (FoMV) and the sorghum isolate (H93) against polyclonal antiserum (IgG) prepared against FoMV-H93 and antiserum made to other viruses

\begin{tabular}{|c|c|c|c|c|c|c|}
\hline \multirow[b]{2}{*}{$\begin{array}{l}\text { IgG source } \\
\text { and dilution }\end{array}$} & \multicolumn{6}{|c|}{ Virus isolate ${ }^{\mathrm{z}}$} \\
\hline & PV139 & H93 & WSMV & MDMV & $\begin{array}{l}\text { SCMV- } \\
\text { MDMV-B }\end{array}$ & JGMV \\
\hline \multicolumn{7}{|l|}{ FoMV-H93 } \\
\hline $1: 100$ & ++++++ & ++++++ & - & - & - & - \\
\hline $1: 200$ & +++++ & ++++ & - & - & - & - \\
\hline $1: 400$ & ++++ & +++ & - & - & - & - \\
\hline $1: 800$ & ++ & ++ & - & - & - & - \\
\hline $1: 1,000$ & ++ & + & - & - & - & - \\
\hline $1: 2,000$ & + & + & - & - & - & - \\
\hline $1: 3,000$ & + & + & - & - & - & - \\
\hline \multicolumn{7}{|l|}{ WSMV } \\
\hline $1: 1,000$ & - & - & ++++ & - & - & - \\
\hline \multicolumn{7}{|l|}{ PVAS 55} \\
\hline $1: 1,000$ & - & - & - & +++ & - & - \\
\hline \multirow{2}{*}{\multicolumn{7}{|c|}{$\begin{array}{l}\text { SCMV- } \\
\text { MDMV-B }\end{array}$}} \\
\hline & & & & & & \\
\hline $1: 1,000$ & - & - & - & - & + & - \\
\hline \multicolumn{7}{|l|}{ JGMV } \\
\hline $1: 1,000$ & - & - & - & - & - & ++++++ \\
\hline
\end{tabular}

${ }^{y}$ An ELISA value was considered positive if it was equal to or greater than twice the value from the equivalent healthy control. A dash (-) indicates a negative ELISA value. ELISA values are represented as: $+=0.200$ to $0.500,++=0.501$ to $0.700,+++=0.701$ to $0.900,++++=0.901$ to 1.100 , $+++++=1.101$ to 1.200 , and $++++++=1.500$ to 1.700 .

${ }^{\mathrm{z}} \mathrm{WSMV}=$ wheat streak mosaic virus Kansas isolate $(\mathrm{H} 94 \mathrm{~S})$, MDMV $=$ maize dwarf mosaic virus (Idaho isolate), SCMV-MDMV-B = sugarcane mosaic virus strain MDMV-B (Ohio isolate), and JGMV = Johnson grass mosaic virus (Kansas isolate).

H93 (Table 2). Antiserum prepared against $\mathrm{H} 93$ reacted specifically to both $\mathrm{H} 93$ and PV 139, indicating that $\mathrm{H} 93$ was serologically related to FoMV. The data also showed that antisera to WSMV, MDMV, SCMV-MDMV-B, and JGMV were negative in ELISA when tested against H93 and PV 139. The antiserum was tested further against CsCl-purified capsid proteins of H93 and PV 139 separated by SDS-PAGE, where the capsid proteins of both migrated to the same location on the gel (Fig. 3A, black arrows). In other ELISAs, antiserum against H93 tested negative against Panicum mosaic virus, as did the $\mathrm{H} 93$ and PV 139 isolates against antiserum prepared against Panicum mosaic virus (data not shown). Western blotting of the counterpart gel resulted in labeling of the bands (arrow $1)$, with no reaction to healthy tissue extracts (lanes 3 and 6) (Fig. 3B). A small band (arrow 2) also was identified only in the Western blot. This band occupied a slightly different position, depending on the virus, and was not present in extracts from healthy tissue isolate, suggesting that it was associated with the virus. This band could represent dimers of the capsid or could reflect a viral protein other than the capsid concomitantly purified with the capsid. Thus, the Western blotting further confirmed the specificity of the antiserum and the serological relationship of $\mathrm{H} 93$ to FoMV-PV 139.

The finding that $\mathrm{H} 93$ is an isolate of FoMV is significant for the following reasons: (i) FoMV was isolated originally 180 $\mathrm{km}$ east of where the H93 isolate was identified; (ii) FoMV had not been reported isolated in nature since 1967; (iii) it had not been shown to naturally infect sorghum; and (iv) it was reported to cause severe symptoms in barley (propagation host for FoMV) while not infecting Johnson grass (14), whereas H93 caused only faint symptoms in barley and infected only a few plants, naturally infected sorghum, infected Johnson grass, and was found each year from 1993 to 1998 in naturally infected sorghum. This difference between the two isolates prompted us to further examine $\mathrm{H} 93$ by comparing it with FoMVPV 139.

Leaf dips again were made from systemically infected GATE 76 sorghum as the propagation host. Both $\mathrm{H} 93$ and PV 139 had flexuous, rod-shaped virions (Fig. 4). In ammonium molybdate, $\mathrm{H} 93$ had virions with a modal length of $489 \mathrm{~nm}$, with an average of $484 \mathrm{~nm}$, but ranged from 460 to $506 \mathrm{~nm}$ (Fig. 4A). In the same buffer, PV 139 had virions with a modal length of $479 \mathrm{~nm}$ and an average of 472 $\mathrm{nm}$ and ranged from 450 to $492 \mathrm{~nm}$ (Fig. 4B). However, when sodium phosphotungstate was used, H93 had shorter virions, with an average of $376 \mathrm{~nm}$ (range from 314 to $459 \mathrm{~nm}$ ), and PV 139 had virions with and average length of $470 \mathrm{~nm}$ (range from 457 to $483 \mathrm{~nm}$ ). Virions of H93 and PV 
A

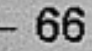

123

456

7

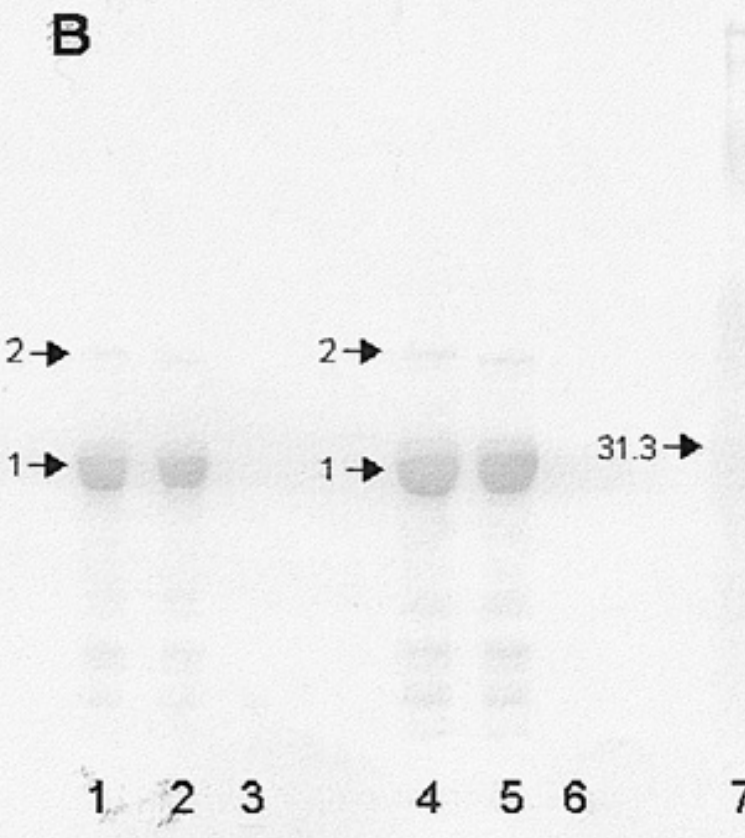

Fig. 3. (A) Protein concentrated from sorghum by minipurification, separated by sodium dodecyl sulfate-polyacrylamide gel electrophoresis; (B) and probed with antibodies to the H93 isolate of foxtail mosaic virus (FoMV) in a Western blot. (A) Lanes 1 to 7: H93 (from $125 \mathrm{mg}$ fresh wt of tissue), H93 (from $250 \mathrm{mg}$ fresh wt of tissue), healthy sorghum (from $125 \mathrm{mg}$ fresh wt of tissue), FoMV-PV139 (from $125 \mathrm{mg}$ fresh wt of tissue), FoMV-PV 139 (from $250 \mathrm{mg}$ fresh wt of tissue), healthy sorghum (from $250 \mathrm{mg}$ fresh wt of tissue), and molecular mass standards, respectively (numbers to right of standards are in $\mathrm{kDa}$ ). Black arrows mark location of band unique to symptomatic sorghum testing negative in enzyme-linked immunosorbent assay. (B) Western blot. Treatments in lanes 1 to 6 are as described for (A). Bands (arrows marked 1) reacting to FoMV (H93) antiserum in the Western blot are equivalent to those marked by arrows in (A). Arrow number 2 marks location of bands reacting faintly to the FMV H93 probe. The 31.3 arrow marks location of prestained soybean trypsin inhibitor marker $(31.3 \mathrm{kDa})$.
139 differed by only $13 \mathrm{~nm}$ (average length) in ammonium molybdate buffer but differed by $94 \mathrm{~nm}$ when phosphotungstate was used. Thus, similar results were obtained for PV 139 using each buffer, but H93 virions were more labile in phosphotungstate, resulting in particle breakage, indicating that ammonium molybdate is the preferred buffer for FoMV analysis in leaf dip experiments. The previously reported
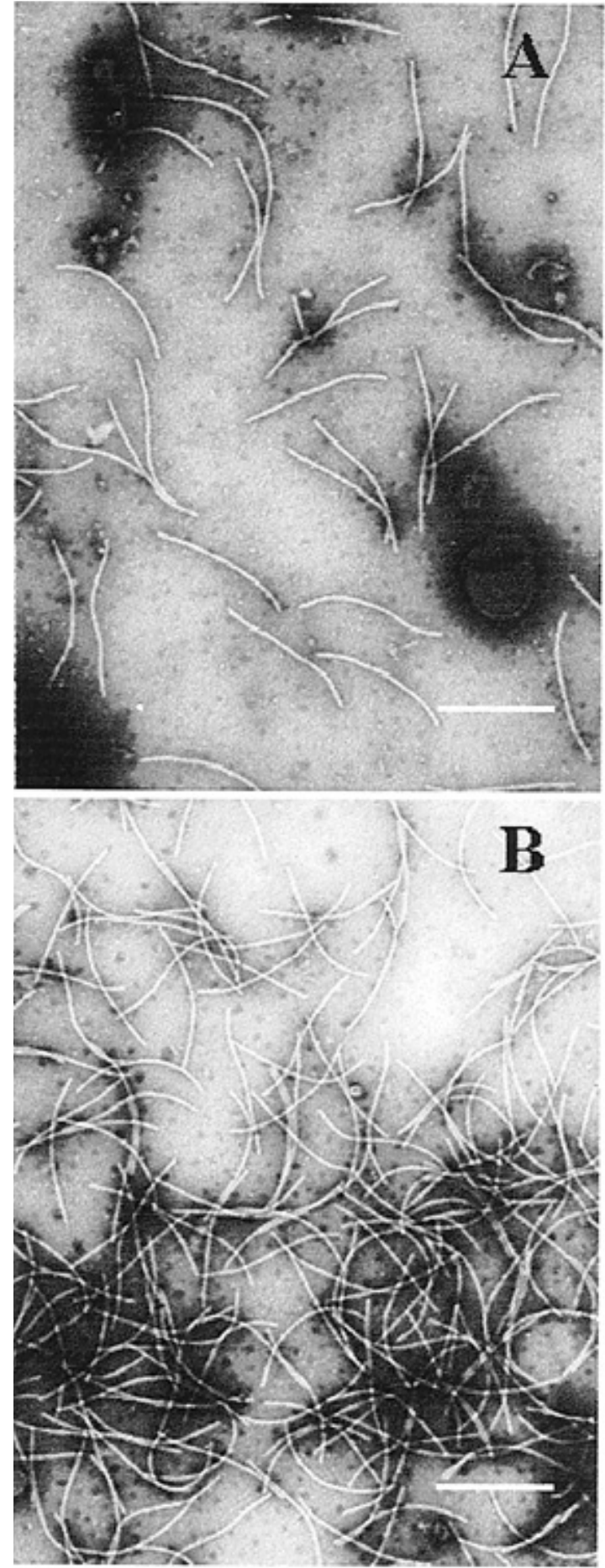

Fig. 4. Flexuous, rod-shaped virions of foxtail mosaic virus prepared from GATE 76 sorghum infected by either the H93 isolate (A) or the PV 139 isolate (B). White bar represents 400 nm. 
modal length of $500 \mathrm{~nm}$ for FoMV (22) is close to our observations for $\mathrm{H} 93$ and PV 139. The difference observed could reflect measuring errors or differences in virions associated with the propagation host, because we propagated both viruses in sorghum, whereas barley was used as the propagation host in previous studies $(14,22)$. Propagation host was shown to influence the length of bean yellow mosaic virus (24).

Because FoMV causes severe mosaic in the barley cv. Reno (14) and we observed that H93 caused only faint symptoms and infected few barley plants, we tested eight barley lines for reactions to both PV 139 and H93. All barley lines infected by PV 139 had prominent mosaic symptoms, whereas H93 induced only faint symptoms. Because of the faint symptoms induced by H93, numbers of infected plants were verified by ELISA, and we found that $\mathrm{H} 93$ infected significantly fewer plants than PV 139 (Table 3). PV 139 infected over twice as many Westford barley plants as H93,

Table 3. Reaction of barley (B) or sorghum (S) plants to mechanical inoculation by either PV 139 or the sorghum isolate (H93) of foxtail mosaic virus (FoMV)

\begin{tabular}{lccc}
\hline Host & Virus & Number of plants & $\begin{array}{c}\text { Arcsine } \\
\text { transformed mean }\end{array}$ \\
\hline Gate 76 S & H93 & $17 / 17$ & $90.00 \mathrm{a}$ \\
Gate 76 S & PV 139 & $26 / 26$ & $90.00 \mathrm{a}$ \\
Otis B & PV 139 & $18 / 20$ & $79.25 \mathrm{ab}$ \\
Lewis B & PV 139 & $20 / 23$ & $78.23 \mathrm{ab}$ \\
Westford B & PV 139 & $20 / 23$ & $77.41 \mathrm{ab}$ \\
Gallatin B & PV 139 & $22 / 25$ & $77.40 \mathrm{ab}$ \\
Westbred Medallion B & PV 139 & $20 / 24$ & $76.05 \mathrm{ab}$ \\
Baronesse B & PV 139 & $21 / 26$ & $73.90 \mathrm{ab}$ \\
Otis B & H93 & $16 / 21$ & $66.21 \mathrm{abc}$ \\
Horsford Hay B & H93 & $19 / 23$ & $65.56 \mathrm{abc}$ \\
Summit B & PV 139 & $19 / 26$ & $64.55 \mathrm{abc}$ \\
Horsford Hay B & PV 139 & $20 / 26$ & $61.71 \mathrm{abc}$ \\
Lewis B & H93 & $13 / 23$ & $50.18 \mathrm{bcd}$ \\
Gallatin B & H93 & $11 / 22$ & $44.38 \mathrm{bcd}$ \\
Westford B & H93 & $9 / 26$ & $34.85 \mathrm{cde}$ \\
Baronesse B & H93 & $4 / 24$ & $24.66 \mathrm{def}$ \\
Summit B & H93 & $2 / 23$ & $14.3 \mathrm{ef}$ \\
Westbred Medallion B & H93 & $1 / 26$ & $6.9 \mathrm{f}$ \\
\hline
\end{tabular}

${ }^{\mathrm{x}}$ Numerator is the number of plants with symptoms and testing positive in enzyme-linked immunosorbent assay (ELISA); denominator is the total number of plants tested. Numbers of infected plants based on three experiments.

${ }^{y}$ Means not followed by the same letter differ according to the Student-Newman-Keul's multiple range test $(P<0.05)$.

${ }^{\mathrm{z}}$ GATE 76 inoculated with the PV 139 isolate was symptomless, but each plant was positive in ELISA against FoMV antiserum.
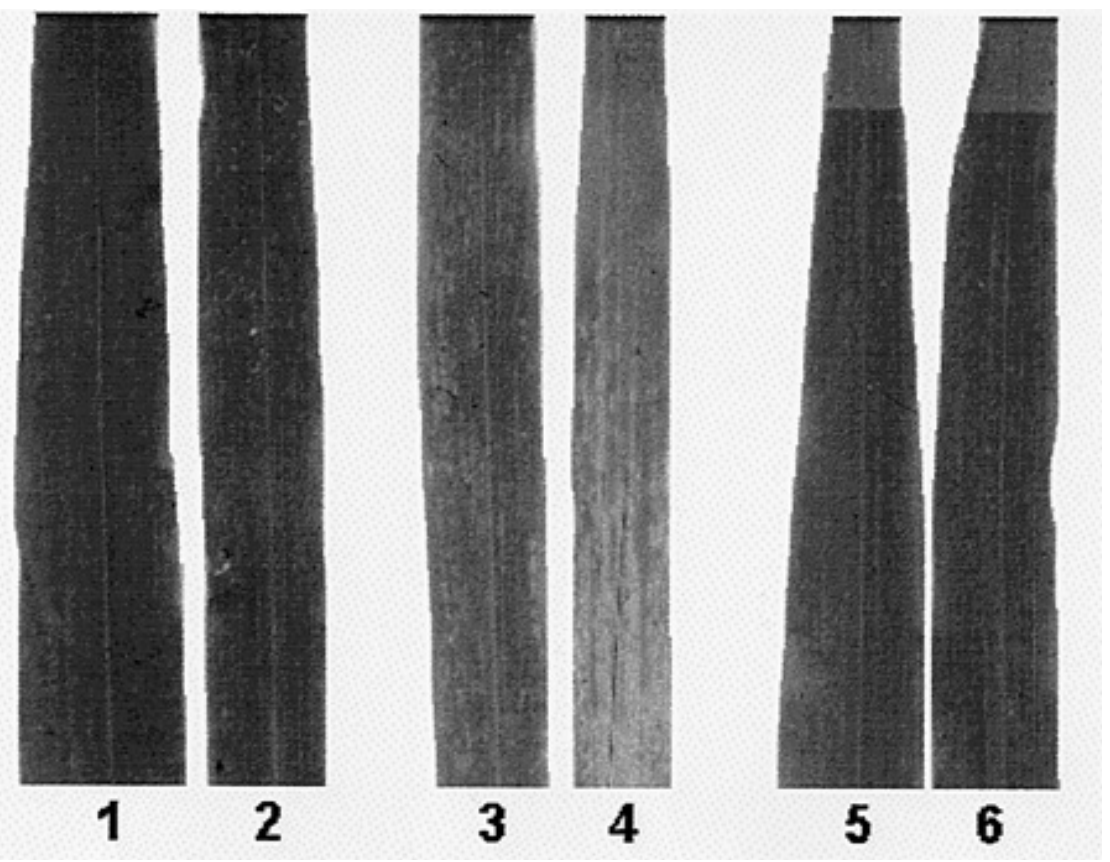

Fig. 5. TX 636B sorghum leaves 3 and 4 (left and right leaves, respectively). 1 and 2, H93-infected; 3 and 4, PV 139-infected; and 5 and 6, healthy control. explaining our original findings where only a few plants were infected and only faint symptoms were observed, which differed from results reported for FoMV in barley (14). Westbred Medallion barley was very difficult to infect by H93, with only one plant $(6.9 \%)$ becoming infected in three experiments compared with the $76 \%$ infection of this cultivar by the PV 139 isolate.

To test the phenotype responses of $\mathrm{H} 93$ and PV 139 on sorghum, the following lines were inoculated: $\mathrm{KS} 57, \mathrm{KS} 5 \mathrm{~B}, \mathrm{KS}$ 69B, TX 2536R, TX 2816, TX 430, TX 626A, and TX 636B. All lines were infected by both isolates; PV 139 caused faint and H93 severe symptoms. This difference was most obvious in TX $636 \mathrm{~B}$ inoculated with either isolate (Fig. 5).

Many plant species previously shown to be hosts for FoMV (14) could be infected with both PV 139 and H93 (Table 4). Among species reported as immune to FoMV (14), we also could not infect $A n$ dropogon hallii, Lolium perenne, and Phalaris arundinacea, but Johnson grass was infected by both isolates. Neither isolate infected Aegilops cylindrica, A. triuncialis, Agropyron elongatum, Alopecurus pratensis, Briza maxima, Panicum antidotale, P. virgatum, and Tripsacum dactyloides with either virus, even though these species were previously reported as susceptible to FoMV (14). The difference in our results with PV 139 probably reflects different seed sources or perhaps inoculation techniques. With both $\mathrm{H} 93$ and PV 139, we successfully infected Zea luxurians, a species not previously tested for susceptibility to FoMV. All species testing positive in ELISA were infectious to GATE 76 sorghum, confirming the ELISA results.

Only sorghum (infected each year), smooth brome (assayed in 1993), and a downy brome (Bromus tectorum) (assayed on 9 June 1997) were found naturally infected with FoMV. Virus in downy brome plant was infectious to GATE 76 sorghum, which in turn tested positive in ELISA only against $\mathrm{H} 93$ antiserum. The identification of the FoMV-infected downy brome plant constituted the earliest observation of the virus in the field from 1993 to 1998. Downy brome was not tested previously as a host for FoMV (14); thus, this study records downy brome, smooth brome, and sorghum as naturally infected by FoMV, in addition to green foxtail in 1967 (14). Also in 1997, the sorghum lines C305, Tx 3042 $\times$ TX 2737, OK11 × TX 2741, and RS 610 were planted after 1 July. Many plants in these rows developed mosaic symptoms and were tested on 3 October 1997. The C305 row contained seven plants, six of which were infected by FoMV (one also infected by JGMV $=0.539)$. The Tx 3042 $\times$ TX 2737 row had 14/14 plants infected by FoMV, the OK11 $\times$ TX 2741 row had 14/15 plants infected by FoMV. The RS 
610 row had three plants all infected by FoMV. An adjacent row of sorghum (unknown pedigree) planted in early June had $7 / 18$ plants with symptoms, of which one was infected by FoMV only, one by FoMV and JGMV, and the remaining five by JGMV. The possible reasons that the late-planted sorghum was more heavily infected by FoMV include more susceptible genotypes, variable plant age, or higher numbers of vectors.

The vector for FoMV is not known (22). We tested greenbugs, corn leaf aphids, and oat-bird cherry aphids for their ability to transmit the H93 isolate from GATE 76 sorghum to healthy sorghum plants. No transmission occurred. Thus, the vector(s) of FoMV causing the natural infection of downy brome, smooth brome, and the yearly infection of sorghum remains unidentified.

The capsid of H93 had an estimated relative mass of $24.3 \mathrm{kDa}$ by SDS-PAGE based on three experiments. Variability in the mobility of potexvirus capsid proteins using SDS-PAGE has been shown for other potexviruses (8). Therefore, we used TOFMS to resolve the mass of the capsid of H93. H93 purified from sorghum had a mass of 23,922 Da from three trials, which differs by $420 \mathrm{Da}$ from the 24,342-Da value derived by SDS-PAGE. The 23,922$\mathrm{Da}$ value is higher than the $21.1 \mathrm{kDa}$ value that was calculated from amino acid analyses (23). Other reported values for the mass of the FoMV capsid are $23.737 \mathrm{kDa}$ (deduced from nucleotide sequence) (2) and $30 \mathrm{kDa}$ using SDS-PAGE analysis for the in vitro translation product (3).

To further characterize the H93 isolate, the purified capsid protein was sequenced using TOFMS (three experiments with identical results). The amino acid sequence for H93 capsid was greater than $96 \%$ identical to that reported by Bancroft et al. (2), further supporting our data that H93 is an isolate of FoMV (Fig. 6). However, it did differ (see dashed consensus line) by having substituted isoleucine (or leucine) for valine at residue 64, insertion of MES between residues 66 and 67, substitution of glutamine for serine at residue 88 , deletion of arginine at position 92, and substitution of aspartic acid for arginine at residues 198 and 206. The predicted mass from the amino acid sequence was 23,893 Da, which differed only by $16 \mathrm{Da}$ from the calculated average. The 23,893 value included the calculated mass of 23,851 plus 42.0 Da for acetylation at the $\mathrm{N}$-terminus, plus $1.97 \mathrm{Da}$ for change of $2 \mathrm{~N}$ residues to $2 \mathrm{D}$ residues, and 2.0 for an intramolecular S-S bond within the residues 93 to 104 . Thus, H93 had 217 amino acid residues, which differs slightly from the 215 reported by Bancroft et al. (2). This difference results from the MES insertion between residues 66 and 67 and a deletion at residue 92 . The 217 and 215 residues reported for H93 and the Bancroft isolate,
Table 4. Reactions of various species inoculated with the sorghum isolate (H93) or the PV 139 isolate of foxtail mosaic virus in host range experiments ${ }^{\mathrm{y}}$

\begin{tabular}{lcccc}
\hline & \multicolumn{4}{c}{ Virus isolate $^{\mathbf{z}}$} \\
\cline { 2 - 5 } Species & H93 & HR & PV 139 & HR \\
\hline Aegilops cylindrica & $0 / 13$ & - & $0 / 15$ & - \\
Aegilops juvenalis & $8 / 15$ & $\mathrm{M}$ & $7 / 15$ & $\mathrm{M}$ \\
Aegilops triuncialis & $0 / 20$ & - & $0 / 17$ & - \\
Agropyron elongatum & $0 / 2$ & - & $0 / 10$ & - \\
Alopecurus pratensis & $0 / 12$ & - & $0 / 14$ & - \\
Andropogon hallii & $0 / 16$ & - & $0 / 18$ & - \\
Briza maxima & $0 / 4$ & - & $0 / 10$ & - \\
Bromus inermis & $1 / 12$ & $\mathrm{FM}$ & $0 / 6$ & - \\
Buchloe dactyloides & $2 / 4$ & $\mathrm{FM}$ & $2 / 4$ & $\mathrm{FM}$ \\
Coix lacryma-jobi & $0 / 14$ & - & $1 / 13$ & $\mathrm{NS}$ \\
Lagurus ovatus & $0 / 16$ & - & $1 / 13$ & $\mathrm{NS}$ \\
Lolium perenne & $0 / 19$ & - & $0 / 18$ & - \\
Oryza sativa & $1 / 22$ & $\mathrm{NS}$ & $0 / 21$ & - \\
Panicum antidotale & $0 / 12$ & - & $0 / 11$ & - \\
Panicum capillare & $0 / 6$ & - & $2 / 6$ & $\mathrm{NS}$ \\
Panicum miliaceum & $3 / 17$ & $\mathrm{NS}$ & $4 / 8$ & $\mathrm{NS}$ \\
Panicum virgatum & $1 / 5$ & $\mathrm{NS}$ & $0 / 5$ & - \\
Paspalum notatum & $1 / 4$ & $\mathrm{NS}$ & $1 / 3$ & $\mathrm{NS}$ \\
Pennisetum glaucum & $5 / 11$ & $\mathrm{M}$ & $2 / 9$ & $\mathrm{FM}$ \\
Phalaris arundinacea & $0 / 15$ & - & $0 / 15$ & - \\
Secale cereale & $2 / 20$ & $\mathrm{M}$ & $1 / 18$ & $\mathrm{M}$ \\
Setaria faberi & $2 / 11$ & $\mathrm{M}$ & $1 / 10$ & $\mathrm{M}$ \\
Setaria italica & $11 / 19$ & $\mathrm{M}$ & $6 / 18$ & $\mathrm{M}$ \\
Setaria viridis & $3 / 14$ & $\mathrm{M}$ & $7 / 13$ & $\mathrm{M}$ \\
Sorghum halepense & $2 / 6$ & $\mathrm{NS}$ & $1 / 6$ & $\mathrm{NS}$ \\
Tripsacum dactyloides & $1 / 4$ & $\mathrm{M}$ & $0 / 5$ & $\mathrm{NS}$ \\
Zea luxurians & $1 / 17$ & $\mathrm{NS}$ & $1 / 17$ & $\mathrm{NS}$ \\
Sorghum bicolor 'GATE 76 ' & $25 / 29$ & $\mathrm{M}$ & $17 / 24$ & $\mathrm{FM}$ \\
\hline - N & & & \\
\hline
\end{tabular}

${ }^{y}$ Number (total of three experiments in most cases) of plants infected over total number of plants inoculated and host reaction (HR) of plants.

$\mathrm{z}_{-}=$not infected, $\mathrm{M}=$ mosaic, $\mathrm{NS}=$ no symptoms, $\mathrm{NT}=$ not tested, $\mathrm{FM}=$ faint mosaic.

\section{MATQNADVTDATDYKKPPAETEQKALTIQPRSNKAPSEE Acetyl-}

41

LVRIINAAQKRGLTPAAFVQAAIVFT MDKGATDSTIFTGK I-- MES

81

YNTFPMKSLALRCKDAGVPVHKLCYFYTKPAYANRRVANQ

121

PPARWTNENVPKANKWAAFDTFDALLDPYWPSSVPYDEP

\section{PALPNNGQYFIEAPQ ------- D --------------}

Fig. 6. Amino acid sequence (determined by time of flight mass spectrometry) of the capsid protein of the sorghum isolate (H93) of foxtail mosaic virus (FoMV) compared with the deduced amino acid sequence determined from the nucleotide sequence. Dashed line (--------) represents a consensus line for amino acids of H93 isolate compared with that published for FoMV (2). Entries or deletions in this line indicate identity and location of differences in amino acids between $\mathrm{H} 93$ and the published FoMV sequence. 
respectively, differ from the 192 residues reported by Short (22) and Short and Davies (23). That difference may result from the analysis techniques. Short used standard Edman degradation procedures and subsequent amino acid analysis, which because of the harsh cleavage conditions can cause the loss or destruction of many commonly occurring modifications in proteins and peptides (5,25-27). Because FoMV has not been reported isolated in nature (except for H93) since 1967 (14), we can assume that Short (22) and Bancroft et al. (2) both used the PV 139 isolate of FoMV. This then lends support for procedural differences causing the differences in the number of amino acid residues reported, particularly because of the close approximation of our results with Bancroft et al.'s (2).

The FoMV, previously thought to be confined to green foxtail, apparently has moved into an agronomically important crop, where it causes significant disease. The virus has been found infecting sorghum each year since it was identified from this species. The epidemiology and economic impact of this new strain of FoMV remain to be determined.

\section{ACKNOWLEDGMENTS}

We thank Jeff Ackerman for his valuable assistance in virus purifications, electrophoresis, ELISA, Western blotting, and other phases of this investigation.

\section{LITERATURE CITED}

1. American Type Culture Collection. 1986. Catalog and registry of the plant viruses. ATCC, Rockville, MD.

2. Bancroft, J. B., Rouleau, M., Johnston, R., Prins, L., and Mackie, G. A. 1991. The entire nucleotide sequence of foxtail mosaic virus
RNA. J. Gen. Virol. 72:2173-2181.

3. Bendena, W. G., and Mackie, G. A. 1986. Translational strategies in potexviruses: Products encoded by clover yellow mosaic virus, foxtail mosaic virus and viola mottle virus RNAs in vitro. Virology 153:220-229.

4. Bollig, D. M., and Edelstein, S. J. 1991. Immunoblotting. Pages 181-208 in: Protein Methods. Wiley-Liss, New York.

5. Carr, S. A., Hemling, M. E., Bean, M. F., and Roberts, G. D. 1991. Integration of mass spectrometry in analytical biotechnology. Anal. Chem. 63:2802-2824.

6. Clark, M. F., and Adams, A. N. 1977. Characteristics of the microplate method of enzyme-linked immunosorbent assay for the detection of plant viruses. J. Gen. Virol. 34:475-483.

7. Great Plains Flora Association. 1991. Flora of the Great Plains. University of Kansas, Lawrence. p. 1219.

8. Koenig, R. 1972. Anomalous behavior of the coat proteins of potato virus $\mathrm{X}$ and cactus virus $\mathrm{X}$ during electrophoresis in dodecyl-sulfate-containing polyacrylamide gels. Virology 50:263-266.

9. Koenig, R., and Lesemann, D. E. 1978. Potexvirus group. Descriptions of Plant Viruses, No. 200. Commonw. Mycol. Inst./Assoc. Appl. Biol., Kew, Eng.

10. Laemmli, U. K. 1970. Cleavage of structural proteins during the assembly of head of bacteriophage T4. Nature 227:680-685.

11. Lane, L. C. 1978. A simple method for stabilizing protein-sulfhydryl groups during SDS-gel electrophoresis. Anal. Biochem. 86:655-664.

12. Lane, L. C. 1986. Propagation and purification of RNA plant viruses. Methods Enzymol. 118:687-696.

13. McDaniel, L. L., and Gordon, D. T. 1985. Identification of a new strain of maize dwarf mosaic virus. Plant Dis. 69:602-607.

14. Paulsen, A. Q., and Niblett, C. L. 1977. Purification and properties of foxtail mosaic virus. Phytopathology 67:1346-1351.

15. Seifers, D. L. 1984. Optimum conditions for studies of maize dwarf mosaic virus strains A and B in sorghum. Plant Dis. 68:1067-1069.
16. Seifers, D. L. 1992. Partial characterization of a Colorado isolate of Agropyron mosaic virus. Plant Dis. 76:564-569.

17. Seifers, D. L., and Caceres, J. 1988. Titer variation in infected sorghum differing in resistance to maize dwarf mosaic virus strain-B. Phytopathology 78:208-212.

18. Seifers, D. L., Harvey, T. L., and Bowden, R. L. 1995. Occurrence and symptom expression of American wheat striate mosaic virus in wheat in Kansas. Plant Dis. 79:853-858.

19. Seifers, D. L., Harvey, T. L., Kofoid, K. D. and Stegmeier, W. D. 1996. Natural infection of pearl millet and sorghum by wheat streak mosaic virus in Kansas. Plant Dis. 80:179. 185.

20. Seifers, D. L., Harvey, T. L., Martin, T. J., and Jensen, S. G. 1997. Identification of the wheat curl mite as the vector of the High Plains virus of corn and wheat. Plant Dis. 81:11611166.

21. She, Y. M., Haber, S., Lobeda, A., Westmacott, G., Perreault, H., Ens, W., and Standing, K. G. 1998. Mass spectrometric characterization of some plant virus coat proteins. Proc. ASMS Conf. Mass Spectrometry Allied Topics, 46th.

22. Short, M. N. 1983. Foxtail mosaic virus Descriptions of Plant Viruses, No. 264. Commonw. Mycol. Inst./Assoc. Appl. Biol. Kew, Eng.

23. Short, M. N., and Davies, J. W. 1987. Host ranges, symptoms and amino acid compositions of eight potexviruses. Ann. Appl. Biol. 110:213-219.

24. Taylor, R. H., and Smith, P. R. 1968. The relationship between bean yellow mosaic virus and pea mosaic virus. Aust. J. Biol. Sci. 21:429-437.

25. Uy, R., and Wold, R. 1977. Posttranslational covalent modification of proteins. Science 198:890-896.

26. Wold, R. 1981. In vivo chemical modification of proteins (post-translational modification). Annu. Rev. Biochem. 50:783-814.

27. Wold, R., and Moldave, K., eds. 1984. Posttranslational modifications, Parts $\mathrm{A}$ and $\mathrm{B}$ Methods Enzymol. Vols. 106 and 107. 